DOI 10.15826/QR.2016.1.155

УДК 327(470)+327(481)+398+811.511.12+327.8

\title{
NORTH BY NORTH-WEST ${ }^{\star 1}$
}

\author{
Gunnar Thorvaldsen \\ University of Tromsø; \\ Tromsø, Norway; \\ Ural Federal University, \\ Yekaterinburg, Russia
}

\begin{abstract}
Rev. of: Nielsen J. P. (red.), Mankova P. (bildered) (2014). Russland kommer noermere: Norge og Russland, 1814-1917. [Russia Comes Closer : Norway and Russia, 1814-1917]. Vol. 1. - Oslo : Pax Forlag. - 642 p.
\end{abstract}

\begin{abstract}
The research project "The Asymmetric Neighbourhood: Norway and Russia 1814-2014" has published two volumes on the history of the relations between Russia and Norway, the first of which, encompassing the period to 1917, is reviewed here. This is a comprehensive publication, covering most aspects of the history of contacts between the two countries. The relations have generally been peaceful, with informal or formal alliances both in the Great Northern War and the Second World War, while boundary issues and questions of sovereignty over Arctic territories have been settled through negotiations. Some of the background for this is the complementary trade relations along the northern coasts, but the relative disinterest in northern areas on the Russian side and common foreign enemies should also be stressed. Much space is naturally devoted to foreign and ethnic politics, but the social history on aspects like Norwegian immigration to the Kola Peninsula may be the highlight of the book, together with the plentiful illustrations. However, quantitative aspects, such as the sizes of different population groups, have been put on the back burner. The editing together of the illustrations and contributions from seventeen authors is exemplary, making the book a delight to read from both aesthetic and scholarly points of view.
\end{abstract}

Keywords: Russia-Norway relations; foreign politics, economic relations, cultural contacts.

* Citation: Thorvaldsen, G. (2016). North by North-West. In Quaestio Rossica. Vol. 4, № 1, p. 287-292. DOI 10.15826/QR.2016.1.155.

Цитирование: Thorvaldsen G. North by North-West // Quaestio Rossica. Vol. 4. 2016. № 1. P. 287-292. DOI 10.15826/QR.2016.1.155.

1 The review work was supported by RNF grant 16-18-10105 "Ethno-religious and demographic dynamics in mountainous Eurasia around 1900. A comparison of the Urals and Scandinavia".

(C) Thorvaldsen G., 2016

Quaestio Rossica • Vol. 4 • 2016 • № 1, p. 287-292 
Исследовательский проект «Асимметричное соседство: Россия и Норвегия, 1814-2014» опубликовал книгу по истории российско-норвежских отношений, первый из двух томов которой рецензируется в данной статье и освещает период до 1917 г. Это многосторонний труд, затрагивающий большинство аспектов истории контактов между названными странами. В целом их отношения были мирными и сопровождались формальным сотрудничеством как во время Северной, так и во время Второй мировой войны, тогда как вопросы о границах и территориальных притязаниях обеих стран в Арктике решались путем переговоров. В книге приводятся сведения о торговле между Норвегией и Россией вдоль северных побережий, однако отмечается, что с российской стороны существенного интереса к северным территориям не было. Издание повествует и об общих врагах Норвегии и России. Значительное внимание по понятным причинам уделяется внешней и этнической политике, но на передний план выходит социальная история, в частности, иммиграция норвежцев на Кольский полуостров. Книга снабжена большим количеством иллюстраций, но, хотя статистических данных, таких как, например, численность различных групп населения, приводится сравнительно немного, высокопрофессиональная редакторская работа, позволившая свести воедино все иллюстрации и тексты семнадцати авторов, делает книгу ценной как с эстетической, так и с научной точки зрения.

Ключевые слова: российско-норвежские отношения; международная политика России и Норвегии; экономические отношения; культурные контакты.

This book is the first of two volumes resulting from the research project "The Asymmetric Neighbourhood: Norway and Russia 1814-2014" richly funded with over 2 million Euros and with eight co-authors from Russia and nine from Norway. The second volume Neighbours in fear and expectation: Norway and Russia 1917-2014 [Holtsmark, Mankova, 2015] has also been published, but both books are major volumes with more than 600 pages, weigh in at over two kilos, have different editors, treat Russia's history before and after the Revolution respectively and thus deserve independent evaluations in book reviews. Fortunately, versions adapted and translated into Russian have been announced to complement the present editions written in Norwegian. The books result from the cooperation between some twenty five historians primarily based at the northern universities, which was intensified from the early 1990s onwards. The writing and editing was started in 2009, and the participating authors report no significant conflicts between themselves or with the authorities. The volumes are richly illustrated with pictures and paintings and look nice on the coffee table in addition to their obvious scholarly merits.

A preamble to these two volumes was published in 2004, even more stressing the rich illustrations with the title translated into English as Norway and Russia: Neighbours during 1000 Years, again with project leader 
Jens Petter Nielsen as one of the editors [Büchten, Dzjakson and Nielsen, 2004]. This functioned as a catalogue for the exhibition with the same name organized in Oslo and St Petersburg in 2004 and 2005. That volume, however, was edited along different guidelines than the recently published ones, since in 2004 each author contributed his or her own chapter, while in the present volumes the editors have combined the contributions from the authors into coherent texts. This is a tour de force made more realistic with information technology and word processing, but all the same required vast efforts on the part of the editors with respect to insights, time and efforts. The method is recommendable, however, since not only does the reader receive a more coherent text, also the contributors have to study each other's contributions thoroughly, thus avoiding repetitions and improving the quality by increasing the level of scholarly inter-subjectivity.

The result becomes even more impressive when considering the broad thematic scope of the books. Plenty of books and articles have been written about aspects of the relationships between Russia and its foreign neighbours, but is harder to find comprehensive publications about many or all aspects of the history of contacts between Russia and one of its neighbouring states. Here is politics, economy, culture; as is indicated by main keywords listed in the library catalogue for the first volume under review here: Culture; Foreign Policy; military; fish; catch; trade; cooperation; History; Barents Sea; Limits; November Treaty; Norway; Fishing (law); Security Policy; Northern Areas; Constitution Anniversary, Sami history; Minority Policy; International Relations. The aim was to celebrate the 200 anniversary of the Norwegian Constitution in 2014 with de lux editions, which the editors and authors managed. ${ }^{2}$ A summary of the book's contents will not be reproduced here, it is available in a lengthy review article [Balsvik, 2015].

The Russian-Norwegian border which was defined in the terrain a long decade after the composition of the Constitution is only 200 kilometres long, and the existence of a no man's land between the two countries for many centuries may illustrate that the northern territories were not viewed as important, especially from the Russian side. The Norwegian coast with its milder climate was more densely populated and used more intensively than the coast of the Kola Peninsula further east. This is the basis for the strongest side of the first volume with its weight on the regional perspective. The focus is more often on the history of relations between people in northern Norway coming into contact with northern Russia and Russians especially while fishing, and their northern Russian counterparts coming into contact with northern Norway and Norwegian especially during the Pomor trade in the summer, rather than on the contacts between Russia and Norway more generally. The regional and often local focus in our age of social history brings us into contact with the history of ordinary people on both sides of the border, providing more important insights than we can glean from many politically and diplomatically oriented histories. Chapter

\footnotetext{
${ }^{2}$ It may have been a tough spurt: the last words in chapter 9 are missing, and the 97 footnotes to chapter 5 are also appended to those belonging to chapter 4 .
} 
10 about the Norwegian settlers on the Murman coast is an excellent example.

This regional perspective, however, becomes more of a drawback in the discussions of geopolitical questions, particularly about the relative lack of conflicts and the long periods of peace. Editor Nielsen maintains that the peaceful relations "were first and foremost based on the difference with respect to resources... Northern Norway's and Northern Russia's ability to mutually fulfil each other's needs. Complementarity was the very nucleus of the Pomor trade..." [Nielsen, Mankova, 63]. That may be making too much out of the fishing and trading, which are most easily eyed from a regional perspective. It is Norway, until 1905 together with Denmark or Sweden, not a regional part of the country, which stayed out of conflict with its major neighbour to the east. For centuries, the significantly stronger attention of the central Russian power towards more important parts of the empire further south and east explains much. Then in the early $18^{\text {th }}$ century, Sweden attacked Russia. Denmark-Norway was a virtual ally siding with Russia in the Great Northern War, even managing to shoot the warrior King Charles the 12 outside a Norwegian fortress and thus putting the decisive end to the conflict. It is true that Norway in formal terms was on the French side when Denmark sided with Napoleon, but not an active participant in his campaign in Russia. When Norway afterwards was transferred from Danish to Swedish sovereignty, this exchange solved a major diplomatic problem for Russia: Sweden was compensated for the loss of Finland. Next, the Russian Tsar and Swedish King as allies during the last Napoleonic War could solve the border issue mentioned above diplomatically, on terms which the Pomor traders found too lenient and unfavourable. There were disputes about the rights to fish in northern waters and about sovereignty over Spitsbergen, but these were solved through international deliberations and without armed conflicts. In the $20^{\text {th }}$ century, relations became intimate with the Norwegian Labour Party joining the $3^{\text {rd }}$ International in 1921-1923 and Russian troops liberating north-eastern Norway in 1944 before pulling out peacefully in 1945. The situation during the cold war from 1949 onwards is a different story.

While the previous point is an interesting topic for discussion, the lack of quantitative information in the book is more of an Achilles' heel. Chapter 8 entitled "Two peasant societies" contain two tables showing average population growth rates in the two countries and some internal regions, but without explaining whether these are arithmetic or geometric averages and what population numbers they are related to. Intensified population growth in Norway towards the end of the $19^{\text {th }}$ century is stressed on page 193 to explain the doubling of the country's population during the century, without mentioning that the population had already nearly doubled in the half-century from 1815 to 1865 . It is good that the Norwegian 1900 census and the Russian 1897 enumeration are used to compare the urban-rural population rates, but we need a reminder that the higher rate in Russia must be understood on the background of its village system, while most 
Norwegian lived on separate farms, cottages etc - as is mentioned a couple of pages earlier. More problematic is that the size of the Sami populations on each side of the border is not compared on the basis of these censuses, which employed language criteria for deciding nationality/ethnicity as recommended at the statistical conference in St Petersburg in 1873. That chapter 13 on the Sami is entitled "Minority and aboriginal politics in the north" is hardly an acceptable excuse.

"North by Northwest" in the title of this review indicates that this history volume about northern relations has been written as part of a research project dominated by viewpoints held by historians in the north-western University of Tromsø, with their strong and weaker sides. ${ }^{3}$ The attentive reader will remember that this is also the title of a masterpiece Hitchcock movie screened to scare the audience with subtle means. This scare is a relevant point with reference to the mental image most Norwegians have had of the Russian bear on its huge territory between Finland and the Pacific Ocean. When Finland was a Grand Duchy under the Tsar from 1809 to 1917, many thought that the Russian danger was approaching and Fins immigrating to northern Norway were perceived as part of this danger by proxy; people spoke and wrote about the Finnish danger. It is not easy to find out what concrete basis there should be for finding the Russian bear so dangerous, except the general and obvious facts that Norway and Russia are very different with respect to size, that Russia could muster bigger armies and had expanded hugely, particularly in the opposite direction. There is no doubt, however, that for those wanting to strengthen Norway's military forces, the big bear in the neighbourhood has been a useful enemy image. This and the relative lack of a reciprocal enemy image on the side of Russian history are well treated in the book.

Other and more minor aspects are less well covered in the book. There were clear differences in demographic factors distinguishing the two populations, which could have been detailed from both primary sources and secondary literature, but this would have required specialized comparative research. The chapter on research in the area shared by Russia and Norway is instructive, but regrettably leaves out cases of most interesting ethnologic studies (Glavatskaya, Thorvaldsen, 2013). One compensation is the rendering of Frithjof Nansen's travel from Tromsø, down the Ob River and on the Trans Siberian Railway, including a stop in Jekaterinburg; here it should be mentioned that his fascinating book on this is easily available on the Internet in Russian and other languages [Nansen; Нансен]. The lack of maps in the new volume when compared with older publications has been criticized by other reviewers, and even if much is available on the web, especially constructed historical maps can be an essential support for the many readers not so familiar with the northern coast of Fennoscandia and Russia - as is shown with the map depicting the Norwegian settlements in chapter 10. More detailed overviews of the contents in each chapter

\footnotetext{
${ }^{3}$ In Russian the film's title is translated «К северу через северо-запад» which misses the double meaning that "by" can also mean "written by".
} 
would have been useful, given the lack of a topic-oriented index. Hopefully, electronic versions of the editions both in Norwegian and in Russian will eventually become available for those needing to refer to the book in their research. Leaving such easy exercises of wishing for more aside: the Russia Comes Closer volume is a worthy crowning both of the research project on the Asymmetrical Relationship and the Norwegian Constitutional Anniversary, as well as an inspiration to read the second volume.

\section{Список литературы}

Balsvik R.-R. Russia and Norway : Research Collaboration and Comparison of Asymmetrical Relations //Acta Borealia. 2015. Vol. 32, no. 1. P. 85-99.

Büchten D., Dzjakson T., Nielsen J.-P. Norge-Russland: naboer gjennom 1000 år. Oslo : Scandinavian Academic Press, 2004. 498 p.

Glavatskaya E., Thorvaldsen G. Sergej Sergel's Field Research in Northern Norway and Finland: Contextualizing Early 20th-Century Sami // Arctic Anthropology. 2013. №. 1 (50). P. 105-119.

Holtsmark S., Mankova P. Naboer i frykt og forventning : Norge og Russland 19172014. Vol. 2. Oslo : Pax, 2015. 748 p.

Nansen F. Gjennom Sibirien. Oslo : Jacob Dybwads forlag, 1914. 386 p. URL: http://www.nb.no/nbsok/nb/e5da0f31acf3762b2463dda6fb487248? index=1\#0 (mode of access: 03.02.2016).

Нансен Ф. В страну будущего Петроград : К. И. Ксидо, 1915. 555 с. URL: http:// www.nb.no/nbsok/nb/f7ba7691557c2d83d6dae5d3bed9a92c.nbdigital?lang=no\#0 (дата обращения: 03.02.2016).

\section{References}

Balsvik, R.-R. (2015). Russia and Norway: Research Collaboration and Comparison of Asymmetrical Relations. In Acta Borealia, 1 (32), pp. 85-99.

Büchten, D., Dzjakson, T. \& Nielsen, J.-P. (2004). Norge-Russland: naboer gjennom 1000 ar. [Norway and Russia: Neighbours during 1000 Years]. 498 p. Oslo : Scandinavian Academic Press.

Glavatskaya, E. \& Thorvaldsen, G. (2013). Sergej Sergel's Field Research in Northern Norway and Finland : Contextualizing Early 20th-Century Sami. In Arctic Anthropology, 1 (50), pp. 105-119.

Holtsmark, S.-G. \& Mankova, P. (2015). Naboer i frykt og forventning: Norge og Russland 1917-2014. [Neighbours in fear and expectation: Norway and Russia 1917-2014]. Vol. 2. 748 p. Oslo, Pax.

Nansen, F. (1914). Through Siberia. 386 p. Oslo, Jacob Dybwads forlag. URL: http:// www.nb.no/nbsok/nb/e5da0f31acf3762b2463dda6fb487248?index $=1 \# 0$ (mode of access: 03.02.2016).

Nansen, F. (1915). V stranu budushchego Petrograd [Through the land of the future Petrograd]. URL: http://www.nb.no/nbsok/nb/f7ba7691557c2d83d6dae5d3bed9a92c. nbdigital? lang=no $\# 0$ (mode of access: 03.02.2016). 